\title{
PASIÓN Y PODER: LA ESCULTURA DE NUESTRO PADRE JESÚS NAZARENO EN ZACATECAS, MÉXICO
}

\author{
JAIME LARA \\ Yale University
}

MARICELA VALVERDE

Universidad Autónoma de Zacatecas

Resumen

Este ensayo estudia una escultura excepcional de finales del siglo XVIII que se encuentra en la ciudad minera de Zacatecas, México. La imagen de tamaño natural es en realidad una escultura de movimiento tipo títere litúrgico, o más bien marioneta, de Jesucristo que actúa dramáticamente en Semana Santa. Se investiga esta imagen dentro de un ambiente más amplio de los títeres medievales, la liturgia de la Iglesia, y nuevas teorías psicológico-sociales. La escultura parece continuar una actitud precolombina al títere como ixiptla o actor-imitador. El resultado novedoso del estudio es que se ha descubierto el mecanismo original que hizo posible que esta escultura "actué" en uno de los más dramáticos momentos de la Pasión.

\section{Palabras claves}

México, títeres, escultura, marioneta, Semana Santa.

\section{PASSION AND POWER: THE SCULPTURE OF JESUS THE NAZARENE IN ZACATECAS, MEXICO}

Abstract

This study examines an exceptional sculpture made toward the end of the XVIII century found in the mining town of Zacatecas, Mexico. The life-size sculpture in question is in reality a liturgical puppet, or rather a marionette, of Jesus Christ that dramatically performs during Holy Week. The image is here studied within the larger context of medieval puppets, the Church's liturgy, and modern psycho-social theories. The sculpture appears to continue a pre-Columbian attitude towards puppets as ixiptla or actor-impersonators. The novelty of the research is the discovery of the mechanism for making this actor "perform" during one of the most dramatic moments of the Passion.

\section{Keywords}

Mexico, puppets, sculpture, marionette, Holy Week.

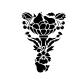

Ucoarte. Revista de Teoría e Historia del Arte, 7, 2018, pp.45-64. ISSN: 2255-1905 
Según los arqueólogos y antropólogos, desde los primeros siglos de la humanidad, el hombre ha creado imágenes de sí mismo que nosotros podemos considerar muñecos o aún títeres. Los historiadores también han notado el uso de muñecos animados por cuerdas entre los egipcios y griegos antiguos, y por ende, la existencia de titereros siglos atrás. ${ }^{1}$ Este estudio pretende analizar una imagen articulada de valor excepcional usada siempre en el contexto afectivo, litúrgico y evangelizador y hasta la actualidad. En la ciudad de Zacatecas se encuentra la escultura que a continuación vamos a describir. Este "títere litúrgico" de Nuestro Padre Jesús Nazareno de la Tres Caídas es una joya colonial que no ha sido estudiado. En este ensayo vamos a tratarlo tanto como una escultura como un implemento de teatro y ritual callejeros, un títere. ${ }^{2} \mathrm{Al}$ emplear la palabra "títere", no pretendemos proponer nada frívolo, sino esperamos abrir un nuevo camino de investigación a la historia del arte aprovechando de teorías psicológicas y sociales del juego, teatro y mimesis. Además, como veremos, nuestra escultura-títere es más precisamente una marioneta, en el sentido clásico de la palabra, y pieza única por varios motivos que vamos a elucidar. Nuestro propósito es traer a la luz esta escultura-títere de Jesucristo y, en segundo plano, una escultura mecánica de la Virgen María que lo acompaña en las representaciones de Semana Santa.

\section{Títeres litúrgicos en la Iglesia}

Aunque su existencia es rara y, en gran parte desconocida hoy, los títeres religiosos eran comunes en la iglesia medieval. ${ }^{3}$ Se originaron en las esculturas tridimensionales y en los autómatas que ganaron renombre en el período carolingio, el siglo IX, que era también el principio de teatralización de la liturgia y los dramas litúrgico-bíblicos realizados en los templos cristianos. ${ }^{4}$ Por la palabra "títere" en un contexto litúrgico, nos referimos a esculturas de Cristo y otros personajes bíblicos, de tamaño natural, cuyos miembros están articulados, es decir, pueden moverse. No son solamente "imagines de vestir" cuyas articulaciones facilitan la vestimenta, sino son esculturas que están manipulados para moverse en momentos de intensa emoción. Los ejemplos existentes más antiguos datan del siglo XII. Uno de los desafíos para la iglesia medieval, fue educar a las multitudes de fieles analfabetos en las narraciones bíblicas y, lo que era más importante, mover sus corazones a re-experimentar esos eventos afectivamente en la actualidad. En los primeros dramas litúrgicos, Jesucristo, la Virgen y otros personajes, fueron interpretados por clérigos vestidos de ornamentos litúrgicos. Estas actuaciones formaban parte de la liturgia como tropos cantados y con poco movimiento. ${ }^{5}$ En siglos posteriores, los personajes sagrados fueron retratados con más teatralidad y movimiento por laicos que usaban máscaras y disfraces. Estas actuaciones se separaron gradualmente de la liturgia propiamente dicha y se convirtieron en lo que llamamos "los misterios", patrocinados por gremios y escenificados al aire libre en el atrio.

Pero en la tradición del Sur de Europa, especialmente en Iberia, los personajes más sagrados eran a menudo interpretados por esculturas o títeres, más que por pobladores cuyas

\footnotetext{
${ }^{1}$ Heródoto, escribiendo en el V siglo a.C., describe procesiones con títeres en Egipto, mientras Platón comenta sobre las acciones de los humanos como las de títeres metafóricos en el siglo IV a.C. Kennard, 1935: 99-102.

${ }^{2}$ No es sin importancia que Zacatecas es una de dos ciudades mexicanas donde se encuentran museos dedicados a los títeres; la otra es Tlaxcala.

${ }^{3}$ Kennard, 1935: 103. La proscripción contra el uso los títeres en la iglesia no ocurrió hasta el Concilio de Trento.

${ }^{4}$ Maldonado, 1975: 243-77.

5 Véase las obras clásicas por Young, 1932: 1:79-197; Varey, 1957: 7-90.
} 
Fig.1. Convento de San Juan Teitipac, Oaxaca. Pintura mural, s. XVI. Rito de la Deposición y procesión. Foto: J. Lara

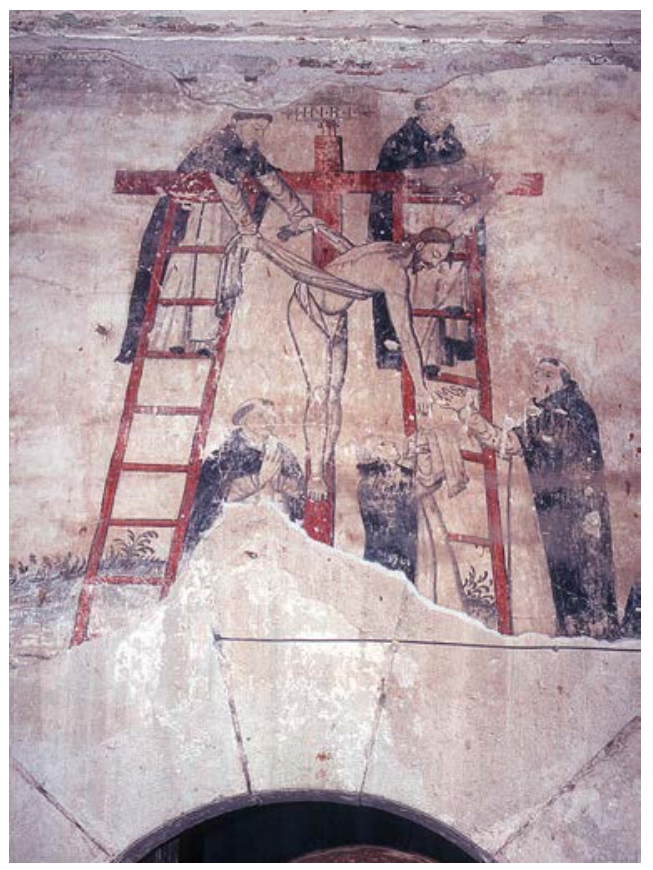

vidas personales o reputaciones podrían no haber estado a la altura de los retratados. Así, para evitar el escándalo o la risa, una escultura o un títere llenó el papel principal en vez de un actor en vivo. Después de la Peste Negra del siglo XIV, estas esculturas-actores cobraron más pathos con la finalidad de conmover el corazón e involucrar el espectador en el sufrimiento expiatorio de Jesucristo. ${ }^{6}$ No había nada supersticioso en esto, como algunos han propuesto; todo el mundo sabía que estaban viendo un títere litúrgico, el cual a menudo exhibía ingeniosos dispositivos para hacer lo sagrado real.

Los títeres litúrgicos se usaban con más frecuencia en la época navideña, durante la Semana Santa, y para la fiesta de Corpus Christi; a veces se colocó en su interior una hostia consagrada. ${ }^{8}$ En el Viernes Santo, el rito de la Deposición de Cristo fue realizado con un crucifijo cuyo corpus podía ser descendido de la cruz; esta práctica continúa en la actualidad. El más famoso en España sigue siendo el Cristo de Burgos, una escultura gótica de madera cubierta de piel de becerro y con labios, cabeza, ojos y extremidades, todos movibles. ${ }^{9}$ En este caso, los brazos son plegables y se pueden doblar contra el cuerpo para que el Señor pueda ser puesto en un ataúd y en el Sepulcro Pascual. ${ }^{10}$ Para aumentar el realismo, el pelo humano se agregó como una peluca, y a la cara como una barba. A veces, un saco de líquido rojo se escondía dentro de la cavidad torácica. En cierto momento, una palanca se presionó contra el saco y la sangre ficticia salió de la herida en el costado. ${ }^{11}$ Estos títeres eran comunes en toda iglesia católica y aún en

${ }^{6}$ Varela Fernandes, 2013; Moyssén, 1967.

${ }^{7}$ Durante la Reforma del siglo XVI hubo muchas quejas acerca de que los rústicos e incrédulos creyeran que los títeres eran personas vivas, pero eso era propaganda protestante. En la Nueva España eran siempre los laicos que mantenían, reparaban y vestían las esculturas articuladas, a veces en sus casas; las conocían bien como artificios.

${ }^{8}$ Sobre la Navidad y Semana Santa como los dos polos de la religiosidad hispana, véase Galilea, 1979: $24-25$. Sobre los dragones tarascos y cabezudos tanto en Europa como en la Nueva España, véase Lara, 2008: 188-90.

${ }^{9}$ Véase Kopania, 2010: 108-11.

10 Para los títeres litúrgicos y el Sepulcro Pascual y su presencia en la Nueva España, véase Lara, 2008: 201-28.

${ }^{11}$ Kopania, 2010: 106-07. 
algunas iglesias luteranas hasta principios del siglo XX, pero el número de títeres litúrgicos similares destruidos en la Reforma tiene que haber sido legión. ${ }^{12}$

Este sentido medieval de la liturgia y su teatralidad cruzó el Atlántico en el siglo XVI con los misioneros mendicantes: los franciscanos, dominicos y agustinos. ${ }^{13}$ Allá en el Nuevo Mundo se encontró con otras formas de teatralidad, aun con títeres prehispánicos.

\section{“Títeres litúrgicos” en las americas}

Cuando los primeros humanos cruzaron el Estrecho de Bering para llegar a América, probablemente traían alguna figura articulada para diversos usos: rituales religiosos, ofrendas o curaciones. En la época prehispánica, hubo vestigios de figuras articuladas para eventos religiosos, muñecos para rituales, de diferentes materiales como arcilla, barro, cetáceo. ${ }^{14}$ Hacen su presencia en el Popul $V u b$ de los mayas:

"Entonces vino la palabra, de los Dominadores, los Poderosos del Cielo [...] decidieron construir al hombre [...] el hombre formado, el hombre maniquí, el hombre moldeado [...] Que así sean, así, vuestros maniquíes, los muñecos construidos de madera, hablando, charlando. [...] Aquellos maniquíes [...] aquellos muñecos. No tenían ingenio ni sabiduría, ningún recuerdo de sus constructores, de sus formadores; andaban, caminaban sin objeto. No se acordaban de los espíritus del cielo; por eso decayeron. Solamente un ensayo, solamente una tentativa de humanidad. Al principio hablaron, pero sus rostros se desecaron; sus pies, sus manos eran sin consistencia; ni sangre, ni humores, ni humedad, ni grasa; mejillas desecadas eran sus rostros; secos sus pies, sus manos; comprimida su carne $[\ldots]$ Éstos fueron los primeros hombres que existieron en la superficie de la tierra."15

Además, los códices precolombinos y las crónicas coloniales relatan que, en los días antiguos, los mexicas o aztecas habían elaborado escenografía, disfraces, máscaras, maquillaje e imágenes portátiles para realizar sus mitos; y la sangre - sangre santa - era siempre parte de sus rituales. ${ }^{16}$ Llamaron tanto sus imágenes como sus actores litúrgicos teotl ixiptla, literalmente "imitador de los dioses". Este sentido de lo dramático no terminó con la llegada del cristianismo. ${ }^{17}$

\section{Títeres coloniales}

La primera mención registrada de títeres entre los españoles es durante la expedición de Hernán Cortés a Honduras en octubre de 1524. Según el cronista Bernal Díaz, el conquistador llevó consigo "un volteador y otro que jugaba de manos y hacía títeres" para entretenimiento. ${ }^{18}$

Entre los pueblos indígenas, los frailes encontraron gran éxito en su empresa misionera cuando utilizaron la música, los dramas bíblicos-catequísticos, la danza y otras formas de arte y

\footnotetext{
12 Satz, 2007: 35-50.

${ }^{13}$ Calzada Martínez, 2011: 34-35 "La tradición y uso de esculturas articuladas pasó pronto de España a la Nueva España, donde tuvo una gran difusión, a juzgar por un gran número de piezas que aún se conservan, y donde adquirió características propias. Existen varios cristos articulados hechos en la técnica de caña de maíz, arte que combinó saberes prehispánicos y españoles, y cuya manufactura se ha dado en el siglo XVI [...]”.

${ }^{14}$ Un títere del segundo milenio a. C. fue descubierto en una tumba en el Perú. Véase Burger/Salazar-Burger, 1998.

15 POPOL-VUH, 2014: 2-18.

16 Duverger, 1978: 129-57; 226-60.

17 Lara, 2004: 6, 157, 177, 182.

18 Díaz, 1960: cap. LXXXIX.
} 


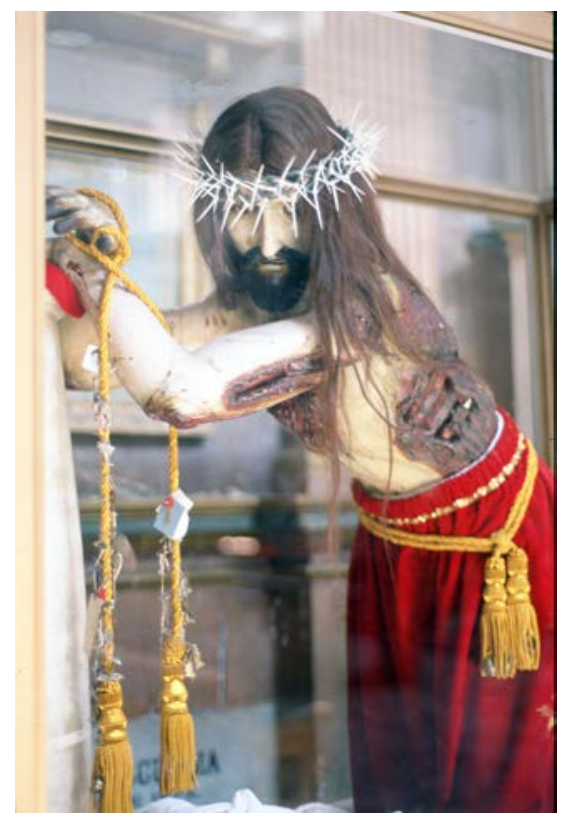

Fig.2. Guanajuato. Iglesia de la Compañía. Imagen de Cristo con huesos insertados. Foto: J. Lara.

parafernalia nativos, para re-imaginar el cristianismo de manera azteca y darle, por así decirlo, un sabor mexica. ${ }^{19}$ La liturgia pre-tridentina transportada al Nuevo Mundo era musical, visual y cenestésicamente atractiva y esa calidad tenía mucho que ver con el éxito de la evangelización. Los títeres y esculturas articuladas eran parte de este éxito porque hicieron lo sagrado real. ${ }^{20}$ Las actuaciones moralistas de títeres eran especialmente populares durante la Cuaresma cuando, tanto en Europa como en América, la ópera y los teatros eran cerrados por ley, y los claustros franciscanos sirvieron para celebrar estos dramas didácticos alternativos. ${ }^{21}$ Debido a su intensidad espiritual y emocional, la Cuaresma fue el momento principal para los rituales que abarcaban lo litúrgico y lo teatral. Una pintura mural de mediados del siglo XVI registra la liturgia de la Deposición en el Viernes Santo y el uso de una escultura articulada de Cristo en el convento dominico de San Juan Teitipac, Oaxaca (Fig. 1). Aquí, los frailes dominicos han trepado escaleras para sacar el corpus de la cruz y luego llevarlo en procesión sobre un ataúd.

Más tarde, en los siglos XVII y XVIII, estas esculturas-títeres se hicieron aún más elaborados, con ojos de cristal, pestañas reales, dientes reales o de marfil, y una peluca de pelo humano que las mujeres de la ciudad se sintieron privilegiadas para donar. ${ }^{22}$ Algunos títeres litúrgicos europeos llegaron a ser verdaderos autómatas con palancas, ruedas y engranajes para hacerlas moverse $^{23}$; y algunos emitieron sonidos de gemidos. ${ }^{24}$ Más común en la esculturas hispánicas fue

19 Véase Revenga Domínguez, 2002: 14-15.

20 "Haciendo el Sacro Real" era el título de una exhibición viajera de escultura española del Museo Nacional de Escultura en Valladolid, 2008-2010; era sumamente sorprendente y popular con los norteamericanos cuando llegó a la National Gallery of Art en Washington, DC.

${ }^{21}$ McPharlin, 1949: 6-7; y Jurado Rojas, 2011: 315-29. El primer titerero novohispano conocido por nombre era Juan Zamora quien ofreció actuaciones moralistas en la Ciudad de México en la Pascua florida de 1569. Hasta fines del siglo XVIII títeres actuaron en dramas religiosas para el Hospital de México como El redentor Jesucristo, el Nacimiento de Jesús, y El más humilde Cordero.

22 Moyssén, 1967: XXXI-XXXIII.

23 Taubert, 1969: 79-121. Todos se usaron en Semana Santa.

24 Welch, 2006: 55-62. 


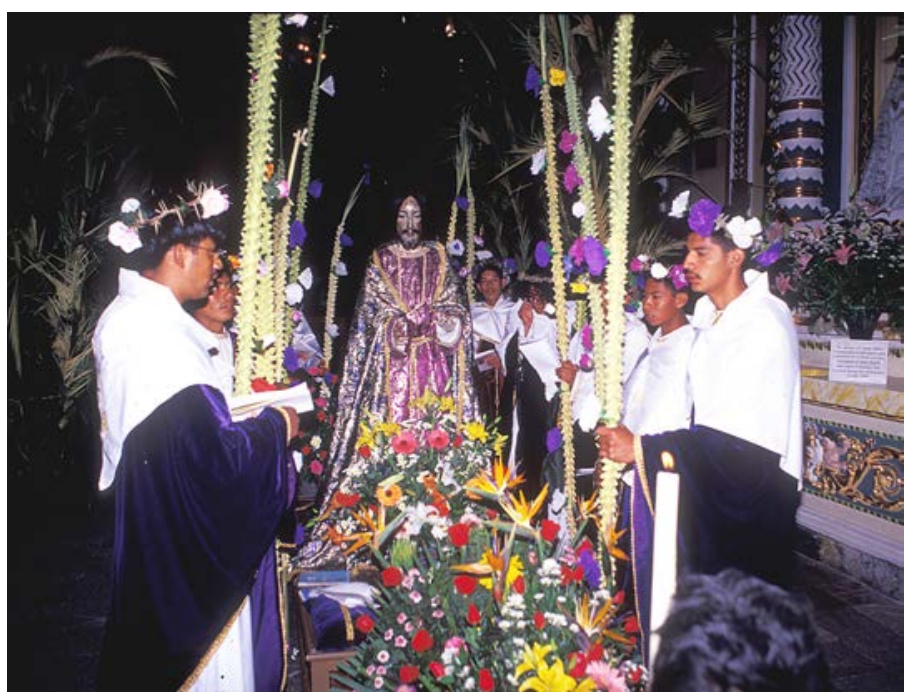

Fig. 3. Santa María Tonantzintla, Puebla. Rito de la Última Cena. Foto: J. Lara.

que a menudo se insertan costillas reales en la "carne" abierta y desollada de la espalda y huesos en los brazos de Cristo, para enfatizar la brutalidad de sus torturadores y para ilustrar versos del Salmo 22 usado en la liturgia del Viernes Santo $^{25}$ (Fig. 2). Este tipo de representaciones ritualistas fue muy utilizado en la Nueva España para reforzar la evangelización. Digno de notar es la mención de los títeres-esculturas de Jesucristo en el Viernes Santo por parte del autor nahua, Domingo San Antón Muñón Chimalpáhin Cuauhtlehuanitzin (1579-1660), un descendiente de los nobles caciques de Amecameca. El las describe como imiquilizyxiptlatzin, literalmente "imitadores enterrados de Dios", la cual perpetúa la idea mexica de la imagen sagrada como personificación, mimesis y actor. ${ }^{26}$ Fue tan impactante el uso de este recurso que continúa siendo útil en la actualidad.

En el contexto de la liturgia del Jueves Santo realizada hoy en Santa María Tonantzintla (Puebla), la escultura de Cristo se articula en la cintura (Fig. 3). Una palanca debajo de las andas permite que la escultura caiga hacia adelante y se golpee en su cara, como se dijo que Jesús había hecho en el Jardín de Getsemaní, o tres veces a lo largo del camino al Calvario. ${ }^{27}$ Observe aquí que la tradición medieval continúa: los doce discípulos son interpretados por actores en vivo, mientras que el actor más importante es un títere. Como veremos, las caídas de Cristo llevando su cruz fueron momentos melodramáticos en la narración de la Pasión y, se prestaban a que los predicadores emplearan metafóricamente para las caídas del creyente en pecado y los momentos de tropiezo de la vida.

25 Salmo 22:17-18 “Como perros, una banda de malvados me ha rodeado por completo; me han desgarrado las manos y los pies. Puedo contarme los huesos".

${ }^{26}$ Chimalpáhin, 2001: 327.

${ }^{27}$ La Vía Dolorosa en Jerusalén y el vía crucis en las parroquias son típicos de la religiosidad franciscana tardomedieval. Véase Pseudo-Bonaventura, 1961. 


\section{El sentido psico-social de los títeres}

Ganamos una perspectiva más profunda al mirar al títere por el lente de las ciencias sociales. Según el teorista de cultura, Johan Huizinga, el hombre es homo ludens, el ser que juega; pero mucho de su juego es serio y terapéutico porque es una forma de lenguaje entre humanos que civiliza una sociedad. Tanto la liturgia como su parafernalia caben dentro de este sentido de "la seriedad del juego". ${ }^{28}$

Varios antropólogos han analizado la importancia del títere en las culturas y especialmente dentro de contexto de ritual y espectáculo. ${ }^{29}$ Lejos de ser entretenimiento para niños y medios de educación en valores, los títeres, como las máscaras, permiten que los participantes proyecten sus sentimientos, angustias, traumas y aspiraciones al exterior en la figura representada. Tal vez más que otras formas de arte, los títeres invitan (y hasta fuerzan) al público a infundir personajes y acción con su propio significado. ${ }^{30}$ En la terminología del antropólogo Víctor Turner, el uso del títere en un ritual es un mecanismo que ayuda a formar communitas, momentos de sentimientos comunes sin estratos sociales, y una respuesta unificada a una tragedia, una situación política-social, o un evento religioso de alta intensidad. ${ }^{31}$ En momentos de communitas los seres humanos no asisten como auditorio pasivo sino como actores activos y co-creadores que, a su manera, contribuyen al drama. ${ }^{32}$

Además, hoy en día es común que los psicólogos emplean títeres en terapia con víctimas de abuso y del trastorno de estrés post-traumático, o bien para ayudar en la expresión del subconsciente. En estos casos, el títere es una proyección de sí mismo. ${ }^{33}$ En algunas culturas antiguas, como la de los aztecas o los japoneses, el títere era un substituto para un dios o bien un muerto de la comunidad. ${ }^{34}$

La antedicha frase "trastorno de estrés postraumático" describe la angustia mental que acompaña a las catástrofes, sean personales o bien colectivas, y los historiadores de arte han encontrado el término útil para examinar ciertas obras artísticas, por ejemplo, los ex-votos. ${ }^{35} \mathrm{El}$ trauma es un acontecimiento violento que el individuo o la comunidad es incapaz de evitar; de hecho, la sensación de impotencia radical es la causa de disturbios fisiológicos a largo plazo tales como pesadillas, ansiedad crónica, culpabilidad, y aislamiento social. Otra consecuencia es que las personas y las comunidades dejan de ver el mundo como significativo; pierden su capacidad de simbolizar e imaginar de maneras saludables. Se han encontrado remedios para esta pérdida, o al menos herramientas saludables, en la elaboración del arte, en formas de juego "serio", y en comportamientos ritualizados que se perciben como reparadores y restauradores. Los rituales y las obras de arte pueden ser terapéuticos precisamente porque crean significados trascendentes, y ofrecen una explicación o un remedio espiritual para lo inexplicable. Como señala el historiador de las religiones Mircea Eliade, el sufrimiento es tolerable en este contexto porque no es absurdo. ${ }^{36}$ Los ritos celebrados en común también permiten una expresión pública de

\footnotetext{
${ }^{28}$ Huizinga, 1955; Turner, 1982.

${ }^{29}$ La compañía Disney ha tenido gran éxito mundialmente con el musical en vivo, El Rey León, el cual usa más de 200 títeres para un espectáculo que recuenta el ciclo de la vida.

${ }^{30}$ Los psicólogos han notado que, después de un tiempo, incluso los adultos suspenden la incredulidad y comienzan a interactuar con marionetas y títeres como si fueran humanos.

31 Turner, 1974, 23-59, también llama esos momentos "experiencias liminales". Durante el conflicto de los Estados Unidos en Vietnam (1960s), la Bread and Butter Puppet Company de Nueva York empleó títeres gigantescos para protestar la guerra y celebrar "liturgias callejeras" en contra de ella.

32 Véase, por ejemplo, Beeman, 1993: 369-393.

33 Por ejemplo, Erwin, 1985: 389-400.

34 Véase Law, 1995: 251-281.

35 Véase Stanfield-Mazzi, 2010.

${ }^{36}$ Eliade, 1965: 98.
} 
sentimientos que normalmente son privados o secretos; y los títeres litúrgicos pueden facilitar esos momentos de communitas, como señala Victor Turner. ${ }^{37}$

Históricamente, después del trauma de la Peste Negra del siglo XIV, las esculturas de Cristo sufriente funcionaron terapéuticamente en las sociedades decimadas como exteriorización del trauma común. ¡Cuanto más cuando las esculturas eran articuladas y dramáticamente tratadas! $!^{38}$ En el caso de representaciones de Jesucristo y la Dolorosa en los rituales públicos, actúan también como substitutos para otras víctimas de delitos actuales, con las cuales los videntes pueden asociarse con empatía. ${ }^{39} \mathrm{La}$ iconicidad del títere (en vez de un actor en vivo) permite la universalidad de la experiencia del sufrimiento en la actualidad de los participantes más que una conmemoración histórica del pasado. ${ }^{40}$ Veremos que tanto el títere-litúrgico de Jesús Nazareno como la escultura mecánica de la Dolorosa que lo acompaña confirman estos entendimientos.

\section{Esculturas articuladas y títeres litúrgicos en Zacatecas}

El culto de Nuestro Padre Jesús Nazareno de las Tres Caídas inicia con los franciscanos y tiene su origen en el Convento de San Francisco en Zacatecas, ubicado en los barrios de indios. ${ }^{41}$ Desde el año de 1546 llegaron a esta ciudad minera de la Gran Chichimeca "indios amigos” venidos del Valle de México, de Tlaxcala y de Michoacán, quienes seguramente conocían la tradición del teotl ixiptla, la santa imagen-actor. Misioneros franciscanos y agustinos llegaron antes del año de 1560 estableciendo doctrinas, hospitales de indios, y varias cofradías para los indígenas. ${ }^{42}$

Los franciscanos contaban con un convento en Zacatecas desde 1566. En el mismo año se constituye la Cofradía de la Santa Vera Cruz en la doctrina de San Francisco. Alrededor del convento se establecieron barrios indígenas y un hospital. La presencia de los indígenas michoacanos fue significativa porque "en 1612 fue nombrado alcalde del barrio de San Francisco de los indios a Juan Agustín natural de Michoacán. La cofradía franciscana de Nuestro Padre Jesús se establece en el mismo año". "Este dato es importante porque en el tiempo colonial el centro de artesanía en madera y la fabricación de escultura y títeres era Michoacán, el cual era también la sede de la provincia franciscana de SS. Pedro y Pablo que abarcaba Zacatecas. ${ }^{44}$

El culto y devoción de Nuestro Padre Jesús Nazareno de Las Tres Caídas, como ya lo sabemos, viene de los frailes de San Francisco. ${ }^{45}$ Queda clarificar que la advocación "padre" para Jesucristo no es una confusión trinitaria, sino una expresión de afecto al Hijo de Dios como el

37 Turner, 1974: 23-59.

38 Véase Frike, 2013: 53-69.

39 En los Andes coloniales, una región asolada por terremotos, maremotos y erupciones de volcanes, las esculturas-títeres participaban activamente en el dolor colectivo; según los cronistas de los siglos XVII y XVIII, hablaban, lloraban o se movían por su cuenta. Véase Lara 2016: 107-119.

40 McKinney, 2011: 221- 235.

${ }^{41}$ Sobre el arte barroco de Zacatecas, véase Tovar y de Teresa, 1981: 207-212; Valverde Ramírez, 2009; Valverde Ramírez, 2013; Valverde Ramírez, 2014.

${ }^{42}$ Rodríguez-Salas, 2005: 39 "Sin duda alguna las más importantes fundaciones hospitalarias colectivas del siglo $\mathrm{XVI}$, tanto por su número como por su extensión geográfica, fueron las que auspiciaron las dos primeras órdenes religiosas que tuvieron a su cargo la evangelización indígena".

43 Archivo de la Parroquia de Zacatecas: caja 145, carpeta 3, foja 1, 23-nov-1658.

${ }^{44}$ Stevens, 2012: intro. Es nuestra opinión que N. P. Jesús Nazareno es producto de un taller michoacano pero comisionado por los franciscanos de Zacatecas.

45 Nuestro agradecimiento al historiador Luis Román Gutiérrez por su invaluable apoyo al facilitarnos los documentos del Archivo de la Parroquia de Zacatecas. Sabemos que hubo cuatro cofradías la de Jesús Nazareno del grupo de los indios ubicado en una ermita o capilla; en el barrio hubo otras cofradías indígenas de Nuestra Señora de la Limpia Concepción, de la Vera Cruz, y de Nuestra Señora de la Asunción. 
Fig. 4. Jesús Nazareno sentado en su trono. Foto: M. Valverde.

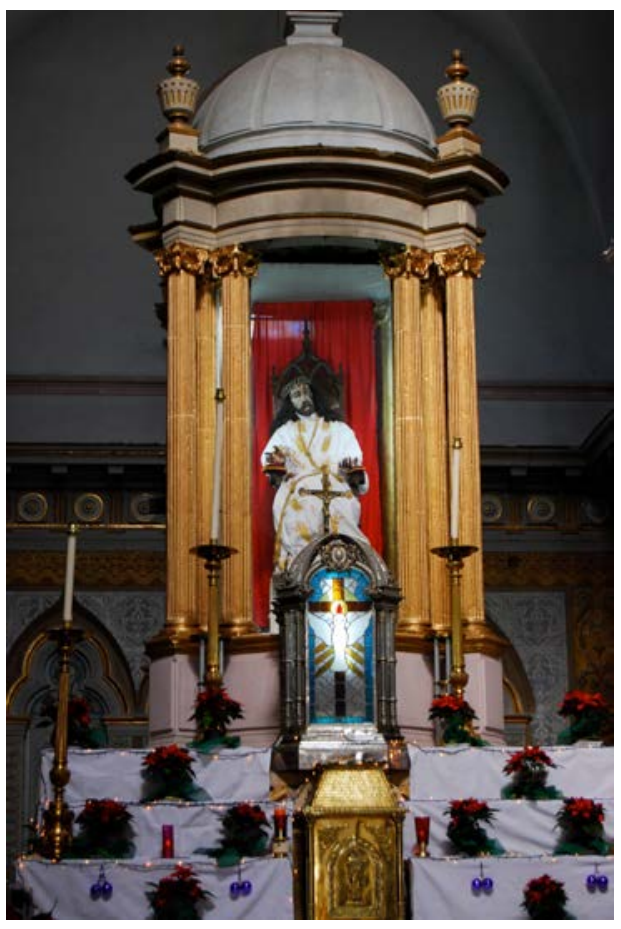

padre-fundador de la cofradía y el modelo de vida y virtud para sus miembros e hijos espirituales. ${ }^{46}$

Las dos esculturas coloniales que vamos a describir están ubicadas en la Parroquia de Nuestro Padre Jesús Nazareno de las Tres Caídas en el barrio de Mexicapan. Dicha parroquia se encuentra a dos cuadras del ex-convento de San Francisco (actualmente Museo Rafael Coronel) y lo que fuera el hospital de los franciscanos (hoy una escuela). ${ }^{47}$

\section{El templo de Nuestro Padre Jesús Nazareno}

La iglesia parroquial de estilo neogótico es de finales del siglo XIX; en la parte lateral exterior está una escultura de cantera de Nuestro Padre Jesús. El templo es pequeño, de una sola nave con cúpula de base octagonal. Arriba del altar principal se ubica el camarín del Cristo enmarcado por dos columnas de cantera de cada lado. Dicha escultura permanece siempre sentada en un pesado trono de madera. Este Cristo es, simultáneamente, el Cristo Rey de Pascua y el Varón de Dolores de Cuaresma que lleva una corona de plata trenzada de espinas. Sus ropas cambiantes, en blanco de Pascua, o rojo o purpura real para Cuaresma, confirman su doble estatus (Fig. 4). La escultura únicamente se baja de su camarín, dos veces al año.

46 Maldonado, 1979: 214-15.

${ }^{47}$ Muy cerca del convento de Zacatecas, los frailes menores levantaron la capilla de Nuestro Padre Jesús, que ya aparece en los planos de la ciudad en el siglo XVIII. Templo reconstruido y agrandado en el siglo XIX por los párrocos Eugenio Narváez y Antonio Soto. Véase López de Lara, 2017: 171. 


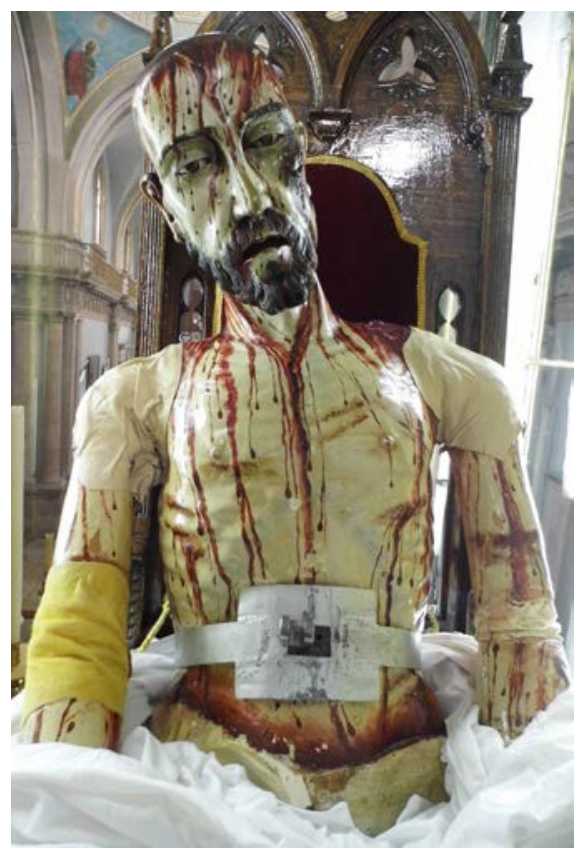

Fig. 5. Torso desnudo del Nazareno con arnés.

Foto: M. Valverde.

\section{A. La bajada en el día de Las Mercedes}

La primera es el día jueves, previo al viernes primero de marzo, que viene siendo el Día de las Mercedes - esto sigue siendo una tradición franciscana. ${ }^{48} \mathrm{El}$ rito consiste en lo siguiente: dentro del camarín la escultura es amarrada al trono; posteriormente, es bajada con todo por los "padrinos". La esperan abajo doce padrinos prominentes; le rezan, le cantan, unos hincados. Luego proceden a "bañar" simbólicamente nada más el padrino de mayor jerarquía, con algodones impregnados en agua y un poco de aceite perfumados. Nunca se le quita totalmente la vestimenta, siempre cubierta la imagen por una sábana blanca. ${ }^{49}$ Después de cambiada la vestimenta, es sentado nuevamente en su trono el Nazareno, dentro de la nave de la parroquia. Dicho rito continúa: todos los feligreses acuden a tocar a la imagen venerada, le rezan los treinta y tres credos que evocan a la vida terrenal de Cristo, y piden tres mercedes.

Los devotos esperan todo el año para solicitar las mercedes; van muchos enfermos, personas con problemas de todo tipo. La imagen es celosamente custodiada por los padrinos quienes le amarran las manos al descanso y colocan los pies encima de un cojín; de esta manera se acercan los feligreses a besarla y tocarla. Le arriman a las manos objetos como rosarios, alhajas (como

${ }^{48}$ Que se inició, según los descendientes, de la Cofradía de Nuestro Padre Jesús Nazareno de las Tres Caídas, hoy llamados "padrinos de lavatorio"; está tradición siempre ha existido desde que los franciscanos trajeron la escultura a Zacatecas. No hay al momento ningún documento que respalde este dato, solamente la tradición oral, que aseguran los padrinos, les han contado sus antepasados.

${ }^{49}$ Los padrinos que son únicamente varones y llevan a sus hijos, también varoncitos, para que continúe la tradición. No se les permite ver en toda su desnudez a la imagen, por considerarlo una falta de respeto. Posteriormente, el agua exprimida la mezclan en seis tinacos grandes; esta agua es repartida en botellas a toda la feligresía, quien asegura que es curativa. 


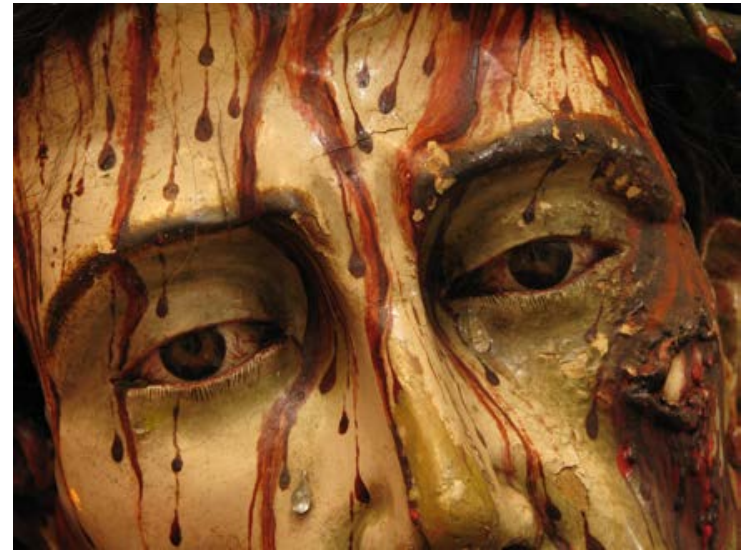

Fig. 6. Por menor, Rostro del Nazareno. Foto: M. Valverde

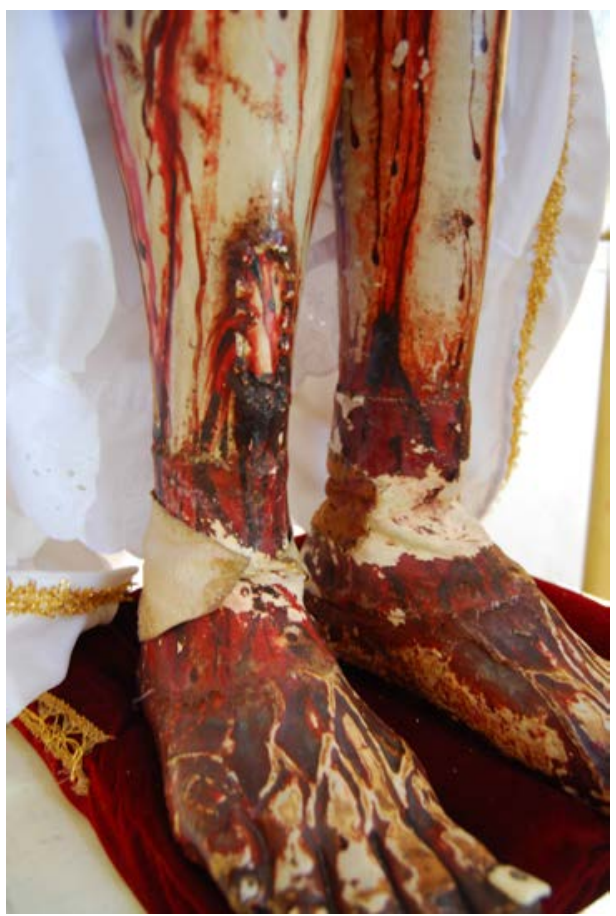

Fig. 7. Por menor de los Pies del Nazareno. Foto: M. Valverde.

medallas y anillos), monedas (para que no les falte el dinero en todo el año), fotografías ${ }^{50}$, etc., para que dichos objetos queden bendecidos. Se llena de gente la nave y las personas esperan horas enteras para acercarse a tocar la imagen, al que consideran su "padre celestial". No deja de asombrarnos que tanto los padrinos así como los feligreses creen que la imagen es milagrosa; además la respetan como si estuviera literalmente moribunda (aún sentado) y en sufrimiento, y por tal motivo quieren tocarla. En este rito se juntan entre cuatro y cinco mil personas.

\section{B. La bajada de Semana Santa}

En la segunda bajada de la escultura en la Semana Mayor se repite el ritual del "baño" antes de hacer la representación propia del Vía Crucis por la mañana del Viernes Santo y, por la noche, la teatral Procesión del Silencio. Para este último se juntan varias órdenes religiosas con los padrinos y demás devotos.

\section{La construcción del títere}

La escultura es de tamaño natural de bulto redondo, procesional y de vestir, para llevar peluca; proporcionada en toda su anatomía. Mide $213 \mathrm{~cm}$ de altura cuando está parado. Tiene articulaciones en los hombros, codos, cintura, ingles, rodillas y tobillos, que le permiten diferentes posiciones. Se puede acostar, sentar, parar, inclinar, levantar brazos y piernas; también

${ }^{50}$ De familiares que por algún motivo no pueden ir físicamente a tocar su imagen, como serían algunos que generalmente están en Estados Unidos o en algún otro lugar, otros están enfermos y, por último, los que ya fallecieron. 


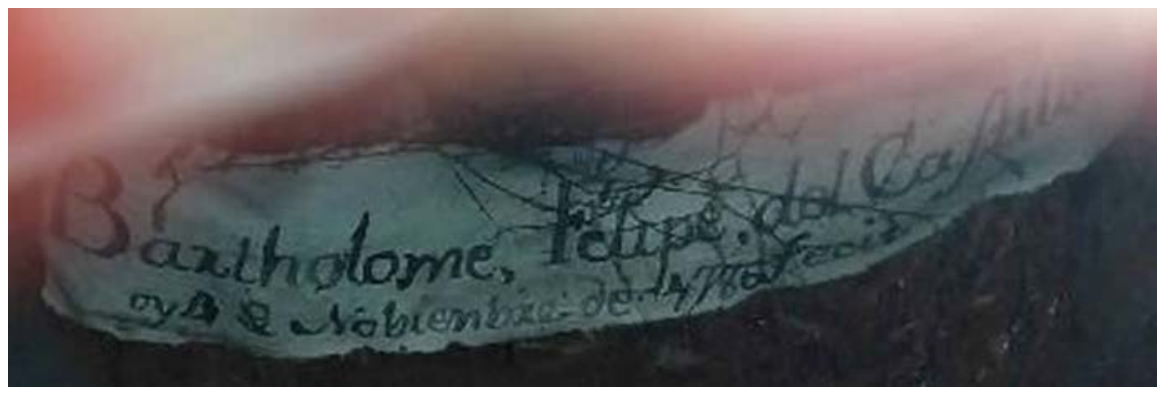

Fig. 8. Firma del supuesto escultor, Bartolomé Felipe del Castillo. Foto: M. Valverde.

realizar la escenificación de las Tres Caídas. Está extremadamente sangrante en todo el cuerpo. Todas las articulaciones iban cubiertas por una delgada y ajustada piel fina, aún se puede apreciar la original en ciertas partes; en otras, se le colocó, recientemente, piel adherida con pegamento industrial.

Como mecanismo principal, la escultura lleva un arnés en la cintura que le permite las posiciones necesarias para caerse al suelo (Fig. 5). Respecto al drama colonial de las Tres Caídas en otras partes de la República Mexicana, comenta la investigadora Hilda Calzada Martínez:

"El mayor rango [alcance] de movimiento lo muestra cuando se representa con él las Tres Caídas; para dicha escenificación participan siete personas: cuatro que cargan las andas, un niño que ayuda a sostener la cruz y dos hombres, que por debajo de las andas, provocan el movimiento. Uno de ellos va bajando poco a poco la varilla que sostiene el torso; mientras el otro, jala los pies hacia atrás para que el Cristo caiga hincado, escenificando así las caídas de Cristo rumbo al Calvario. En cada pie lleva fijada una barra de metal con dos ruedas; estas ruedas pudieron haber estado sobre una base con rieles, donde se deslizaban, resultando el movimiento más suave y continuo". ${ }^{1}$

Como veremos más adelante, este no es la manera en que el títere fue usado en el siglo XVIII, sino es una solución moderna. El Cristo que comenta Calzada Martínez tiene un mecanismo parecido a la escultura que nos ocupa, pero no tan sofisticado como la nuestra.

Para los actores en el teatro, la expresión de la cara es de suma importancia, así también con nuestra escultura (Fig.6). De rostro hermoso y conmovedor, delgado, con ligero hundimiento en las mejillas levemente inclinado hacia adelante. Tiene ojos de vidrio de color café; en el globo ocular, se aprecian venas ramificadas de color púrpura. Este efecto de las venitas es verdaderamente impresionante; el canto externo e interno ensangrentados; el iris lleva varios cortes que lo hacen parecer más natural, y las líneas interiores también están sangrantes.

Los párpados superiores ligeramente abultados, las ojeras también tenuemente hundidas, efecto que acentúa el sufrimiento. Se ven restos de pestaña de cabello natural en la parte superior de los ojos y, en la inferior, van pintadas con pincel muy fino. Esto es también en toda la parte donde lleva cabello pintado. Las cejas con pliegues y coloreadas con una línea horizontal, seguida y acompañada por delgadas líneas verticales. Lleva lágrimas de resina; boca entreabierta, más de lo acostumbrado.

\footnotetext{
51 Calzada Martínez, 2011: 64.
} 


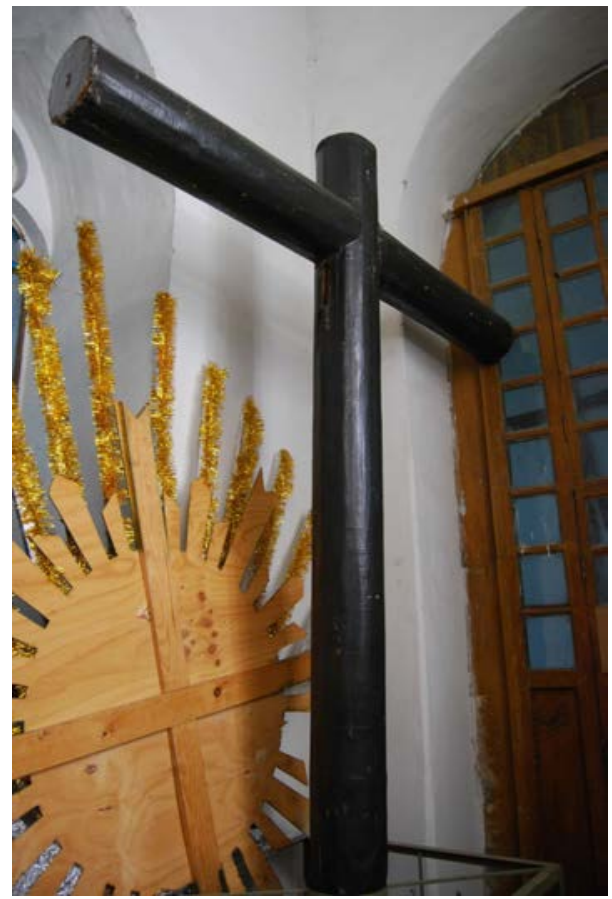

Fig. 9. Cruz bueca que originalmente contenía las cuerdas para operar la marioneta de Jesús Nazareno. Foto: J. Lara

Del lado derecho de la cara una herida reventada lleva un hueso incrustado, el llamado "beso de Judas" (Fig. 6). Al respecto: "El beso de Judas aparece en el pómulo de Jesús como una herida tremenda, como una pústula que ha reventado para desalojar el veneno maldito de la traición". ${ }^{52}$ La herida está mencionada frecuentemente en la literatura devocional - la "pasión secreta de Jesucristo" - del Norte de Europa que tuvo mucho impacto en España y en el Nuevo Mundo. ${ }^{53}$ La cara no lleva cabello tallado, únicamente la barba y bigote delgados, pocas ondulaciones, apretados con rigidez; al final, la barba se divide en dos. La nariz recta y delgada. En la parte de arriba de la cabeza, tiene una placa metálica, dos tornillos y un orificio en medio. De cuello largo y delgado; bien trabajados los músculos y la clavícula. Las orejas proporcionadas para la cabeza.

En el hombro derecho lleva una armella; en el izquierdo, un orificio (¿moderno?) para atornillar la cruz en la posición de Cristo cargando su cruz. Las articulaciones de los hombros son ensamble gozne o de paleta; hace un giro de $180^{\circ}$ que le permite subir y bajar los brazos, pegados a la cabeza y a la pierna. Ambas articulaciones están cubiertas burdamente por piel adherida con pegamento industrial reciente. En el brazo derecho lleva cubriendo la articulación con sobre posición de piel. El torso con buena anatomía; se aprecian las costillas, así como el hundimiento del abdomen.

El hecho de que hay tanta sangre pintada en el torso, la espalda y los brazos indica que originalmente la imagen no fue vestida de túnica sino solo de taparrabos. La espalda está ensangrentada, exageradamente lacerada, reventada, con inserción de delgados huesecillos. ${ }^{54} \mathrm{En}$ la parte de atrás, a la altura del coxis, lleva una armella. Respecto a los codos, lleva articulación de esfera, gira $360^{\circ}$, lo cual permite la movilidad a cualquier lado.

Ambas manos abiertas, largas, con los dedos delgados y flexionados; al centro de las palmas en una tiene una armella; y en la otra únicamente está el orificio. En la muñeca lleva huesos

\footnotetext{
52 Moyssén, 1967: XVII.

53 Véase Marrow, 1979, para la "pasión secreta" de Jesucristo escondida en el Libro de los Salmos.

${ }^{54}$ Como casi todos los cristos en México.
} 
incrustados. Sobresale el tallado de las manos, con unas venas bien trabajadas; las uñas de marfil. La articulación de la entrepierna y unida a las piernas está cubierta, primero con ixtle (fibra vegetal) y, encima, piel pegada, clavada y cosida, al menos en la parte de enfrente que fue la única que pudimos ver; se aprecian clavos de fierro antiguos.

Consideramos que esta articulación es original y que no tiene ninguna intervención, únicamente, el deterioro normal por el movimiento. Es muy probable que la parte inferior del torso tenga algunos rebajes la madera, que es lo que le permite la flexibilidad en la cintura y las piernas. Las piernas son proporcionadas al cuerpo, de muslos gruesos, piernas largas; en la pantorrilla derecha tiene una herida reventada, con dos huesos incrustados, uno ancho y, encima, uno delgado; alrededor de la herida, pequeños huesillos.

En las rodillas lleva articulación de esfera. Respecto a los pies, están articulados en los tobillos que es lo que le permite el movimiento. Los pies son de muy buena factura, al igual que las manos; y emergen las venas. En la planta de los pies, lleva una placa de metal, cubierta con ixtle, encima piel ajustada y clavada, que debió de ocultar todo el metal; en los talones lleva una armella; en el pie derecho, entre el dedo gordo, lleva también una armella (Fig. 7). Observando las muchas armellas en el cuerpo, nosotros empezamos a darnos cuenta que el títere litúrgico era en realidad una marioneta en el sentido clásico como una figura animada desde arriba por cuerdas o hilos. ¿Pero cómo?

Los pies también llevan, por la parte de arriba, cubierta con ixtle; encima, piel ajustada, lo anterior pintado de rojo. Las uñas originales se perdieron con el desgaste del mecanismo y también al ser tocado y besado por los fieles; se aprecia que fueron incrustadas a la madera, como las uñas de las manos. Ahora, llevan algunas, una placa de marfil sujeta con un clavito de fierro. El pie derecho las lleva todas; el izquierdo, nada más en el dedo gordo y el meñique. En el dedo gordo del pie derecho se aprecia un clavo antiguo. Hay pérdida en algunas partes de la policromía, en otras está agrietada como se puede observar en la nariz, dedos de las manos y pies; al parecer la espalda está intacta de esta pérdida.

Respecto a los dientes, llama la atención que no se le ve uno solo; si las uñas de pies y manos son de marfil ${ }^{55}$, es posible que también lo fueran los dientes y se los quitaron, o bien eran de animal o humano como en otras esculturas coloniales. ${ }^{56}$ Únicamente, se le aprecia la lengua que es de un material blando. Gran sorpresa para nosotros fue descubrir, escrito en la garganta: Bartholome Felipe del Castillo noviembre de 1786 Fecit (Fig. 8). Hasta el momento no hemos podido encontrar datos acerca de este escultor ${ }^{57}$; pero la fecha es importante porque representa el poder y la riqueza de la cofradía hacia fines del siglo XVIII.

Con nuestro descubrimiento de las múltiples armellas y el hecho de que el títere era en realidad una marioneta, originalmente pensamos que había una especie de superestructura encima de la plataforma desde la cual se suspendieron la cruz y el títere. Creíamos - como anotó Hilda Calzada Martínez arriba - que uno o más operadores estaban ocultos bajo las andas y, en un momento determinado de la procesión, permitieron que la cruz cayera al suelo y Cristo con ella. Pero estábamos equivocados. Al inspeccionar la cruz (Fig. 9), descubrimos que es a propósito hueca, y un soporte de metal indica que estaba fijada a la plataforma en un ángulo de aproximadamente $30^{\circ}$. Examinando una rendija bajo el brazo horizontal, descubrimos poleas dentro de dicha

\footnotetext{
${ }^{55}$ Respecto a la llegada del marfil a Zacatecas, hemos localizado algunos cristos talla en marfil y dos vírgenes con rostro y manos de marfil; por los ojos rasgados sabemos que llegaron de las Filipinas, en la época colonial. Véase Sánchez Navarro de Pintado, 1985. Los franciscanos del ex-convento de la Propaganda Fide de Guadalupe, Zac., en su inventario del siglo XVIII de la iglesia y sacristía, anotan "a un Señor San José chiquito de bulto, de marfil", "una crucecita de marfil con Cristo de lo mismo", en Rafael Cervantes Aguilar, "Documentos Mecanografiados Simple". Inédito.

${ }^{56}$ Excélsior, 2018.

${ }^{57}$ Hubo un español, Antonio del Castillo, escultor antequerano (1635-1704) famoso por sus imágenes de Jesús Nazareno y la Dolorosa; nuestro artista pueda ser su hijo.
} 


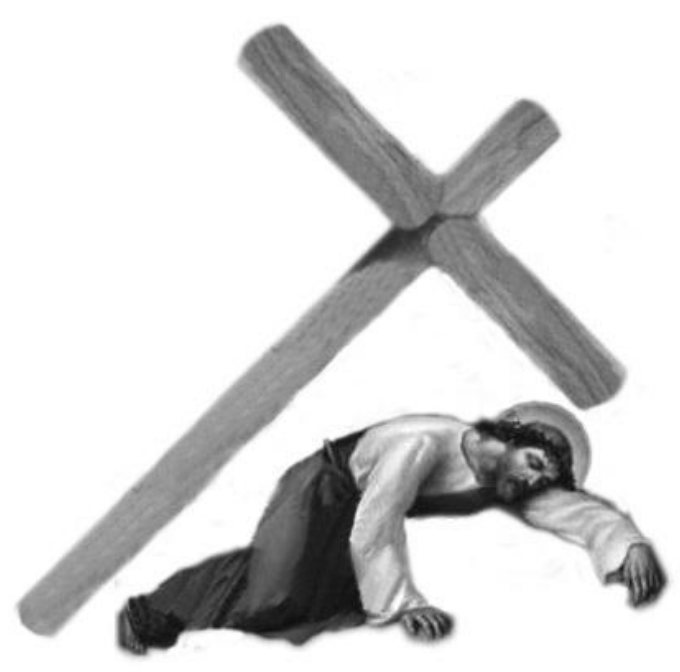

Fig. 10. Dibujo de la marioneta en el momento de las caídas. Por Roberto Chávez Montes.

estructura hueca. Esto nos indicó que las cuerdas o hilos corrían desde los titiriteros debajo de las andas, por dentro de la cruz y hacia fuera de la abertura a las diversas partes del cuerpo de la escultura (Fig. 10). En un momento dado, un titiritero podía tirar los pies de Cristo hacia atrás en una pista/carril oculta para hacerlo arrodillarse o caerse postrado, mientras otros titiriteros bajaban o levantaban el torso, la cabeza y los miembros de Cristo. Con el transcurso de los años, el constante movimiento de giro y giro ha causado estragos en las articulaciones, de ahí su mala condición.

Puede ser que se realizaba este movimiento de las Tres Caídas todavía a mediados del siglo XX; actualmente ya no se hace. Según la información recabada, los padrinos no sabían exactamente como se activaba el mecanismo ni que la escultura es una marioneta. ${ }^{58}$ Lo que sí conocían era que todo se activaba debajo de las andas ocultas con lienzo.

\section{Virgen Dolorosa}

Brevemente trataremos de una escultura mecánica y auxiliar. El drama de la Pasión es por supuesto incompleto sin la Virgen María, quien es a la vez una persona histórica como también representativa de toda la comunidad cristiana. El Viernes Santo ella sale de la iglesia para acompañar a su Hijo sufriente en el camino al Calvario (Fig. 11). Una mirada más cercana a la Virgen revela que una espada está clavada en su pecho, una cita literal de Lucas 2:35 "Y una espada traspasará tu propia alma, para que los pensamientos de muchos corazones sean revelados," usada en la liturgia.

La cabeza y manos son tallados en madera; la vestimenta de vestido insinuado, en tela encolada; encima, viste diferentes vestidos, de tela negra con bordados dorados. El rostro es conmovedor, expresivo, hermoso y dulce a la vez, a pesar de su dolor; la mirada hacia arriba;

\footnotetext{
${ }^{58}$ Los abuelos y padres no les permitían ver, ni se lo quisieron decir a los más jóvenes, o sea, a sus hijos.
} 


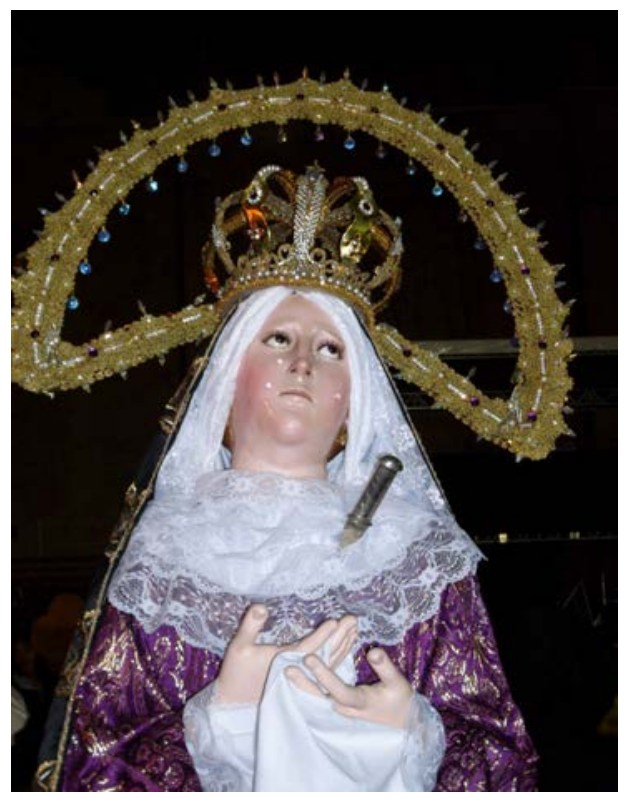

Fig. 11. La escultura articulada de la Virgen Dolorosa. Foto: M. Valverde.

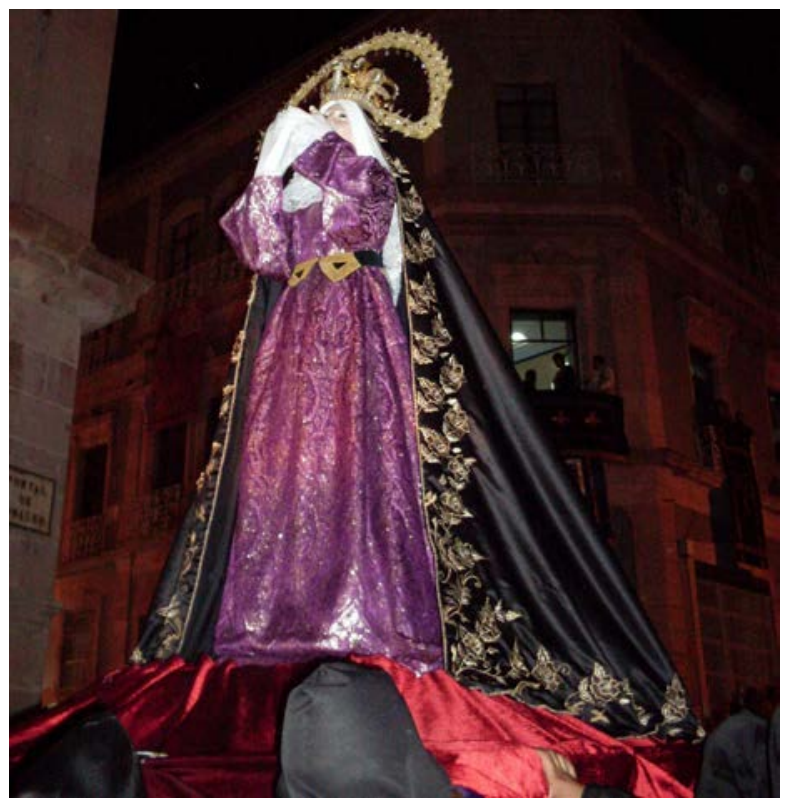

Fig. 12. La Dolorosa cuando levanta el pañuelo a la cara. Foto: M. Valverde.

ojos de vidrio, lágrimas de cristal; pestañas de cabello natural, cejas delineadas con pinceladas delgadas; ceño fruncido; boca entreabierta, dientes de hueso; puñal de plata. Se puede apreciar que el rostro y manos están retocados; la escultura tiene base de madera. La imagen lleva piel en las articulaciones para el movimiento en los brazos y codos.

La escultura levanta sus manos en tres posiciones, que van activando los padrinos al momento de las tres caídas (Fig. 12). La Virgen tiene un mecanismo manual que consiste en lo siguiente: una armella a la altura de la espalda, donde va un cordel que la atraviesa; además, sostiene los brazos y, de ahí, la jalan los cófrades a la altura del ruedo del vestido y la escultura levanta las manos en las tres posiciones (Fig. 13). Debieron de haber sincronizado estos movimientos con las caídas de Jesucristo. Es impresionante este acto, ya que la Virgen lleva un blanco pañuelo en sus manos y, en la tercera posición, ella se cubre el rostro con él. Por tener el mecanismo, en este caso para levantar las manos en tres tiempos, que a cada caída había un movimiento coordinado de las manos de la Virgen también en tres tiempos, para complementar la tradición del santo encuentro a lo largo de la Vía Dolorosa. Además, la antropología y la psicología nos enseñan que personas representativas (o esculturas de tales personas) como la Virgen ayudan a los seres sufrientes de hoy a expresar compasión, empatía y solidaridad en momentos de trauma y horrible crueldad.

Finalmente, hemos localizado a dos esculturas que pensamos que son las originales y han acompañado al Nazareno y la Virgen: María Magdalena y San Juan Evangelista; trataremos de estas esculturas en un ensayo futuro. 
Fig. 13. El mecanismo de la Dolorosa. Foto: M. Valverde.

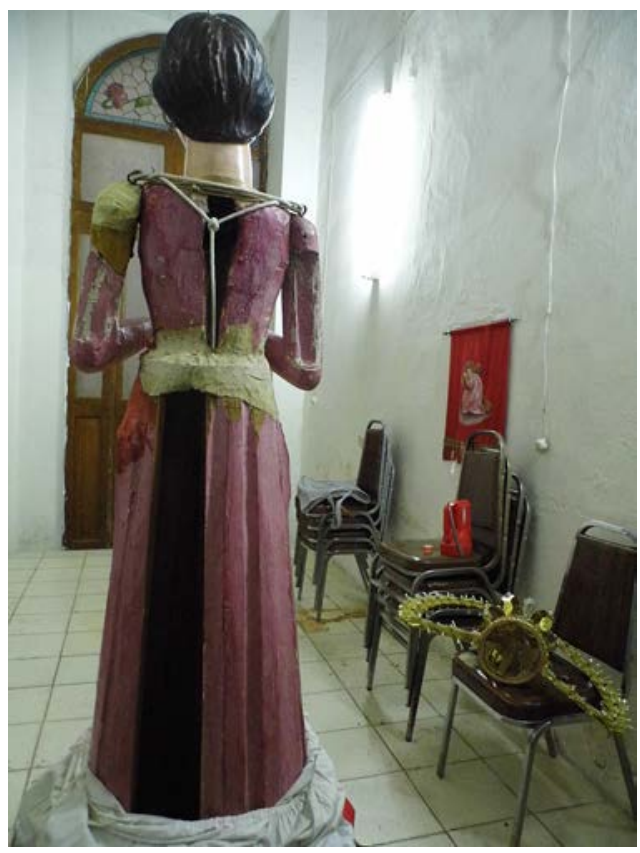

\section{Conclusiones}

El tipo de representaciones ritualistas que hemos presentado es muy importante para la historia del arte virreinal y principalmente en el Estado de Zacatecas, puerta del septentrión evangelizadora hacia el norte de la Nueva España y más allá. ${ }^{59}$ Tenemos suficientes elementos para apoyar nuestra teoría de que la marioneta de Nuestro Padre Jesús Nazareno de las Tres Caídas ha sido sacada en procesión desde que la mandaron hacer los franciscanos en la octava década de siglo XVIII. Queda la probabilidad que hubo una escultura anterior, pero menos satisfactoria, desde cuando fundaron la cofradía de Nuestro Padre Jesús; recordemos que fue en el año de 1566 cuando se le dio el nombre al barrio de San Francisco y se constituye la cofradía hospitalaria de la Santa Vera Cruz.

La tradición medieval de procesiones con imágenes-actores está desapareciendo por varios motivos, entre otros, que se comenzaron a realizar Vía Crucis vivientes imitando las películas bíblicas de Hollywood. Consideramos que es oportuno rescatar el conocimiento del antedicho tipo de representaciones ritualistas y teatro religioso callejero con imágenes-actores. Los franciscanos, sobre todos, nos legaron varias esculturas y títeres religiosos para el gran drama de la Pasión; la escultura que nos ocupó en este ensayo es impactante tanto por su construcción como por su técnica. Nos alegramos sacar a la luz el mecanismo que permitía el movimiento de las tres caídas y mostrar que es una marioneta ingenua. Consideramos que esta escultura-títere es una joya en la corona del arte virreinal y una expresión de las dinámicas psico-sociales más profundas de los seres humanos.

59 Zacatecas era la base de evangelización franciscana hacia lo que hoy es Nuevo México (EE.UU.) donde los Hermanos Penitentes todavía usan primitivos títeres de Jesucristo para desempeñar sus rituales secretos. Sería interesante averiguar si la influencia venía de una experiencia de esculturas-actores virreinales, como la de Zacatecas. 
Mariciela Valverde y Jaime Lara

\section{BIBLIOGRAFIA}

Beeman, W.: "The Anthropology of Theater and Spectacle". En Annual Review of Anthropology, (1993), pp. 369-393.

Burger, Richard, y Salazar-Burger, L.: "Front matter". En RES: Anthropology and Aesthetics 33. (1998).

Calzada Martínez, H.: La Escultura Articulada en el Distrito Federal: Arte, Ingenio y Movimiento, Tesis de Maestría. México: Universidad Autónoma de México. (2011).

Chimalpáhin, D.: Diario. Traducido por Rafael Tena. México: Conacultura. (2001).

Díaz, Bernal: Historia verdadera de la conquista de la Nueva España. México: Porrúa. (1960).

Duverger, C: L'esprit du jeu chez les Aztèques. Paris: Mouton Éditeur. (1978).

Eliade, M.: The Myth of the Eternal Return. Princeton: Princeton University Press. (1965).

Erwin, E.C.: "Puppets in Therapy: An Assessment Procedure". En American Journal of Psychotherapy, 39, (1985), pp. 389-400.

Excélsior: "INAH: El Cristo de la Paciencia en Zumpango tiene dientes de humano". Excélsior, periódico, México D.F. https://www.excelsior.com.mx/expresiones/2014/08/06/974670. Consultado en agosto de 2018. (2014).

Frike, B.: "A Liquid History: Blood and Animation in Late Medieval Art". En RES: Anthropology and Aesthetics 63, (2013), pp.53-69.

Galilea, S.: Religiosidad populary pastoral. Madrid: Cristiandad. (1979).

Huizinga, J.: Homo Ludens: A Study of the Play-Element in Culture. Boston: Beacon Press. (1955)

Jurado Rojas, J.: "Puppet Theater in Eighteenth-Century Mexico". En The Americas 67, (2011), pp.315-29.

Kennard, J. S.: Masks and Marionettes. Port Washington, NY: Kennikat Press. (1935).

Kopania, K.: Animated Sculptures of the Crucified Christ in the Religious Culture of the Latin Middle Ages. Varsovia: Wydawnictwo Neriton. (2010).

Lara, J.: City, Temple, Stage: Eschatological Architecture and Liturgical Theatrics in New Spain. Notre Dame, Indiana: University of Notre Dame Press. (2004).

Lara, J.: Christian Texts for Aztecs: Art and Liturgy in Colonial Mexico. Notre Dame, Indiana: University of Notre Dame Press. (2008)

Lara, J.: Birdman of Assisi: Art and the Apocalyptic in the Colonial Andes. Tempe, Arizona: Arizona Center for Medieval and Renaissance Studies. (2016).

Law, J.M.: Religious Reflections on the Human Body. Indianápolis: Indiana University Press. (1995).

López de Lara, J.: Zacatecas, historia, cultura y arte. Apuntamientos para la historia de la Iglesia Católica en Zacatecas. México: Secretaria de Cultura INAH. (2017).

Maldonado, L.: Religiosidad Popular: Nostalgia de lo mágico. Madrid: Cristiandad. (1975).

Maldonado, L.: Génesis del catolicismo popular: El inconsciente colectivo de un proceso histórico. Madrid: Cristiandad. (1979).

Marrow, J.: Passion Iconography in Northern European Art of the Late Middle Ages and Early Renaissance. Kortrijk: Van Ghemmert. (1979).

McKinney, J.: "Empathy and Exchange: Audience Experience of Scenography". En Kinesthetic Empathy in Creative and Cultural Practices, (2011), pp. $221-235$.

McPharlin, P.: The Puppet Theatre in America: A History. Nueva York: Harper. (1949).

Moyssén, X.: México: Angustia de sus cristos. México: Instituto Nacional de Antropología e Historia. (1967)

POPOL-VUH o Libro del Consejo de los Indios Quichés: Instituto Cultural Quetzalcóatl de Antropología Psicoanalítica. En www.samaelgnosis.net, págs. 2 a 18. Consultado en abril del 2014.

Pseudo-Buenaventura: Meditations on the Life of Christ: An Illustrated Manuscript of the Fourteenth Century. Isa Ragusa y Rosalie Green, eds. Princeton, NJ: Princeton University Press. (1961). 
Revenga Domínguez, P.: "Iconografía de Santiago el Mayor. Las representaciones del santo de los dos mundos, entre el relato bíblico y la leyenda". En El apóstol Santiago en el arte, cat. exp., 5-25. Cali: Fondo de Promoción de la Cultura. (2012)

Rodríguez-Salas, $\mathrm{M}^{\mathrm{a}}$ L.: El Hospital Real de los naturales, sus administradores y sus cirujanos 1531-1764 ¿miembros de un estamento profesional o de una comunidad cientifica? México: Universidad Nacional Autónoma de México. (2005).

Sánchez Navarro, B. de P.: Marfiles cristianos del oriente en México. México: Fomento Cultural Banamex. (1985).

Satz, A.: "Attacks on Automata and Eviscerated Sculptures". En Iconoclasm: Contested Objects, Stacy Boldrick y Richard Clay, eds., 61-81. Farnham, Inglaterra: Ashgate. (2007).

Stanfield-Mazzi, M.: "In the Aftermath of Crisis: The Painted Ex-Voto in Colonial Peru". Latin American Studies Association. http://lasa.international.pitt.edu/members/congresspapers/lasa2010/files/2615.pdf. (2010). Consultado en abril del 2014.

Stevens, B.: Mexican Masks and Puppets. Atglen, Pensilvania: Schliffer. (2012).

Taubert, G. y J.: "Mittelalterliche Kruzifixe mit schwenbaren Armen". En Zeitschrift des deutschen Vereins für Kunstwissenschaft 23, (1969), pp. 79-121.

Tovar y de Teresa, G.: México Barroco. México: Editorial SAHOP. (1981).

Turner, V.: Dramas, Fields, and Metaphors: Symbolic Action in Human Society. Ithaca, Nueva York: Cornell University Press. (1974).

Turner, V.: From Ritual to Drama: The Human Seriousness of Play. Nueva York: Performing Arts Publications. (1982).

Valverde Ramírez, M.: Ignacio Berbén, un pintor del Reino de la Nueva Galicia Siglo XVIII. Jalisco: Amateditorial. (2009).

Valverde Ramírez, M.: Zacatecas arcón de joyas virreinales. México: Editorial Texere. (2013).

Valverde Ramírez, M.: Descripción iconográfica de las claves de la catedral de Zacatecas, en Martín Gerardo Luna Tumoine, Las claves de catedral. México: Editorial Multicolor. (2014).

Varela Fernandes, C.: "Pathos - the bodies of Christ on the Cross, rhetoric of suffering." Journal of the International Association of Research Institutes in the History of Art, 78, (2013), (sin paginación)

Varey, J.E.: Historia de los titeres en España. Madrid: Revista de Occidente. (1957).

Welch, E.: "The Moaning Crucifixion: An Automata for Francisco Sforza". En Arte e storia di Lombardia: Scritti in memoria di Grazioso Sironi, 55-62. Florencia: Società Editrice Dante Alighieri. (2006).

Young, K.: The Drama of the Medieval Church, 2 v. Oxford: Oxford University Press. (1932). 


\section{Anexo 1}

Dimensiones de las esculturas

\begin{tabular}{|c|c|c|c|c|}
\hline ESCULTURA & FECHA & TÉCNICA & DIMENSIONES & $\begin{array}{l}\text { PESO } \\
\text { APROXIMADO }\end{array}$ \\
\hline $\begin{array}{l}\text { NUESTRO } \\
\text { PADRE JESÚS } \\
\text { NAZARENO }\end{array}$ & $\begin{array}{l}\text { NOVIEMBRE DE } 1786 . \\
\text { AUTOR:BARTHOLOME } \\
\text { FELIPE DEL CASTILLO }\end{array}$ & $\begin{array}{l}\text { PINO } \\
\text { POLICROMADO }\end{array}$ & $\begin{array}{l}\text { ALTURA } \\
\text { PARADO } 213 \text { CMS. } \\
\text { SENTADO } 100 \text { CMS }\end{array}$ & $80 \mathrm{KG}$. \\
\hline $\begin{array}{l}\text { CRUZ DEL } \\
\text { CRISTO }\end{array}$ & NOVIEMBRE DE 1786. & \begin{tabular}{lr}
\multicolumn{1}{c}{ CARRIZO } & Y \\
LISTONES & DE \\
MADERA, & \\
RECUBIERTA & POR \\
DOS FORROS & DE \\
TELA & \\
ENCOLADA;LLEVA \\
ALGUNAS & \\
ARMELLAS & \\
\end{tabular} & \begin{tabular}{|r} 
\\
LARGUERO 327 \\
CMS. TRAVESAÑO \\
230 r CMS. \\
DIAMETRO 73 CMS \\
\end{tabular} & $30 \mathrm{KG}$ \\
\hline $\begin{array}{l}\text { VIRGEN } \\
\text { DOLOROSA }\end{array}$ & $\begin{array}{l}\text { PROBABLEMENTE } \\
\text { 1786? }\end{array}$ & \begin{tabular}{lr}
\multicolumn{2}{c|}{ IMAGEN } \\
PROCESIONAL DE \\
VESTIR, TALLA EN \\
MADERA \\
POLICROMADA EN \\
ROSTRO Y MANOS, \\
SOBRE BASTIDOR; \\
LLEVA r VARIOS \\
LISTONES & DE \\
MADERA & QUE \\
ENLAZAN EN & LA \\
CINTURA. & \\
\end{tabular} & $\begin{array}{l}\text { PARADA } 165 \\
\text { CMS. CINTURA } 80 \\
\text { CMS. } \\
\\
\end{array}$ & $25 \mathrm{KG}$ \\
\hline
\end{tabular}

